Article

\title{
Breeding Progress in Seedling Resistance against Various Races of Stripe and Leaf Rust in European Bread Wheat
}

\author{
Holger Zetzsche *, Albrecht Serfling, Frank Ordon \\ Julius Kuehn-Institute (JKI), Federal Research Centre for Cultivated Plants, \\ Institute for Resistance Research and Stress Tolerance, Erwin-Baur-Strasse 27, \\ 06484 Quedlinburg, Germany \\ * Correspondence: Holger Zetzsche, Email: holger.zetzsche@julius-kuehn.de; \\ Tel.: +49-3946-47-305.
}

\begin{abstract}
Background: Stripe and leaf rust are major constraints of wheat production with substantial impacts on grain yield. Population dynamics of both pathogens and the emergence of new virulent races have resulted in relentless efforts related to wheat breeding to improve resistance during the last decades.
\end{abstract}

Methods: To evaluate the breeding progress achieved with respect to racespecific resistance, a set of nine isolates of the two rust pathogens have been tested in seedling assays on a panel of 191 elite winter wheat cultivars representing wheat breeding in Europe between 1966 and 2013.

Results: Significant differences in the resistance of wheat cultivars concerning both pathogens have been detected by means of two-way ANOVA. Isolates as well as genotype $\times$ isolate interaction had a significant effect for both pathogens. Breeding progress, resulting in an increased seedling resistance, has been achieved against all nine isolates over the past five decades. The slope of progress was steeper for leaf rust than for stripe rust isolates. Progress against the highly common leaf rust isolate " 4171 " and" the stripe rust isolate "Warrior(-)" was strongest.

Conclusions: The study reveals that a steady increase in seedling resistance

\section{G Open Access}

Received: 26 June 2019

Accepted: 11 October 2019

Published: 14 October 2019

Copyright $(0) 2019$ by the

author(s). Licensee Hapres,

London, United Kingdom. This is an open access article distributed under the terms and conditions of Creative Commons Attribution 4.0 International License. was achieved during the past five decades. An additive contribution of these isolate specific R genes after breakdown has been hypothesised.

KEYWORDS: Triticum aestivum; Puccinia striiformis f.sp. tritici; Puccinia triticina; fungal pathogen; rust; isolates; seedling resistance; R genes; breeding progress

\section{INTRODUCTION}

Stripe and leaf rust, caused by the fungal pathogens Puccinia striiformis f.sp. tritici (PS) and Puccinia triticina (PT), are major constraints of wheat (Triticum aestivum L.) cultivated under temperate climatic conditions with a substantial impact on grain yield [1-3]. Biological control through the 
utilisation of resistance genes has been applied in wheat as a cost-effective and ecologically friendly means to avoid yield losses. However, the rise of new virulent races and their dispersal have resulted in considerable intraspecific variation, which have dynamically altered the importance of single pathogen races within years $[4,5]$.

Two types of genes have been distinguished to mediate resistance against rusts in wheat. Seedling resistance (R) genes expressed at all growth stages are regarded as race-specific and qualitative, while adult plant resistance (APR) effective in later growth stages is described as primarily quantitative [6,7]. In general, $R$ genes in plants often encode nucleotide-binding site leucine-rich repeat (NBS-LRR) proteins and recognise specific pathogen effectors, also referred to as avirulence proteins, in a gene-for-gene mode [7]. $R$ genes tend to have greater effects but have been reported to lose their effectiveness mostly after several years [7,8]. APR genes appear to encode different proteins, such as ABC transporter, protein kinase, or hexose transporter [7,9]. Although genes involved in APR may lose their efficacy as well, some are described as slow-rusting APR genes [10]. A high level of durable resistance can be achieved by pyramiding either ARP or R genes or by stacking several APR and $\mathrm{R}$ genes [7,11].

The dynamics of pathogen races virulent against particular resistance genes required continuous efforts in wheat breeding during the past decades. As a result, multiple stripe rust and leaf rust resistance genes ( $\mathrm{r}$ and $L r$ ) of both types of resistance have been introduced into elite wheat cultivars [12]. The following common $\mathrm{Yr}$ genes were identified in European cultivars: $Y r 1, Y r 2, Y r 6, Y r 9, Y r 17$, and $Y r 32$, [13]. $L r$ genes, such as $L r 1, L r 3, L r 10, L r 13, L r 14 a, L r 24, L r 26$, and $L r 37$, were the most common genes against leaf rust $[14,15]$. Unfortunately, virulent $P S$ races that are able to overcome resistance genes which have been introduced more recently, such as $\mathrm{Yr} 10, \mathrm{Yr} 24$, and $\mathrm{Yr} 27$, have already been reported [16-18]. Moreover, resistance genes, such as $\operatorname{Yr} 5$ and Yr15, which are still effective to date are rarely or never employed in European elite wheat cultivars [13,19]. $L r$ genes used in elite cultivars are also mostly race-specific, and most of these have already been overcome [17,20], including resistance gene Lr37 which is carried by many cultivars registered in Germany [21]. Similar to $P S$ races, $P T$ races recently prevalent in Germany carry multiple virulence genes against most of the resistance genes present in elite wheat cultivars [22].

Breeding progress in economically successful European winter wheat was investigated in field trials with respect to production intensity, including the impact of fungal pathogens [23]. Accordingly, a steady decrease in susceptibility to stripe rust and powdery mildew of adult plants was detected in the past five decades. These results confirmed a previous report of a significant improvement of German wheat cultivars relative to several fungal pathogens, including leaf rust, over the same period [24]. 
The present study aims to investigate the susceptibility and breeding progress in seedling resistance against different isolates of stripe and leaf rust in high-yielding winter wheat cultivars released in Europe in the past 50 years.

\section{MATERIALS AND METHODS}

\section{Plant Material}

A panel of 191 wheat cultivars was selected for their agronomic importance in wheat production in Western Europe, particularly in Germany, during their release period between 1966 and 2013 [23]. All cultivars aside from the hybrids were replicated by self-pollination under field conditions. Seeds of hybrids ( $F_{1}$ seeds) were provided by the respective breeding companies. The test panel represents long-term plant breeding progress in Western Europe. Details including the year and country of registration are provided in the supplementary information of [23].

\section{Rust Isolates}

All isolates of both rust pathogens were initially derived from single pustules on the susceptible genotypes "Akteur" (stripe rust) and "Borenos" (leaf rust). Races of P. striiformis (PS: "Warrior(-)", "Warrior + Yr27”, "Oakley,v7/Kranich", "Triticale aggressive") were determined through virulence analysis by K. Flath (JKI Kleinmachnow) and multiplied according to [25]. Virulences of P. triticina isolates (PT: "4083", "4171", “77WxR", "FI17”, "HkLr13”) were determined according to [22]. Lr12, Lr13, Lr22, Lr35, Lr37, and Lr46 are race-specific APR genes [7,20,26,27] carried by near isogenic lines (NILs) and have been included into the virulence analysis according to [20]. Virulence against all of these $L r$ genes was observed at the seedling stage (Table 1, marked by bold letters and asterisk). All isolates were increased so that a sufficient number of spores was available for inoculation. After multiplication, $P S$ and $P T$ spores were dried using a desiccator and stored at $5{ }^{\circ} \mathrm{C}$ until inoculation within 10 days.

\section{Seedling Tests}

Seedling assays were performed in semi-controlled greenhouse conditions between November 2017 and April 2018 (PS) and between September 2018 and May 2019 (PT), respectively. Three seedlings of each cultivar, each with two replicates per isolate, were grown in $7 \times 11$ potting trays filled with soil substrate Fruhstorfer Typ T (Hawita Gruppe GmbH, Vechta, Germany) and raised at $21{ }^{\circ} \mathrm{C}$ until the second leaf was fully expanded. Seedlings were prepared for inoculation by spraying with $0.005 \%$ aqueous Tween ${ }^{\circledR} 20$ (Carl Roth GmhH+Co.KG, Karlsruhe, Germany) to facilitate the even adhesion of spores to the leaves. Inoculation was performed with 50 milligrams of urediniospores of each isolate mixed with clay (1:2) using a powder atomiser. Subsequently, seedling assays 
were incubated under plastic hoods at $100 \%$ humidity for $24 \mathrm{~h}$ ( $P S$ at $5-8{ }^{\circ} \mathrm{C}, P T$ at $\left.16-18^{\circ} \mathrm{C}\right)$. To maximise infection, seedlings were then grown at $10-12{ }^{\circ} \mathrm{C}$ for $P S$ and at $18-20^{\circ} \mathrm{C}$ for $P T$ at a photoperiod of $14 / 10 \mathrm{~h}$ with supplementary lighting. Seedlings were scored for both infection types (resistant: “0”, “;”, “N;”, “1”; moderately susceptible: “2”; susceptible: “3”, "4") on a modified scale according to [8] and the percentage of leaf area infected based on [28], which is restricted to visible sporulation. Stripe rust was phenotyped 14 days after inoculation and leaf rust after 10 days, respectively.

\section{Statistical Analysis}

Descriptive and summary statistics of infection types and the percentage of leaf area infected by both pathogens were calculated using the statistical software JMP 14.0.0 from [29]. Relative susceptibility was calculated based on [30], combining infection type and the percentage of leaf area infected (\%LAinf) to receive robust and continuous data to estimate breeding progress for resistance. First, infection type data were transformed into continuous data based on [31]. Pearson's correlation coefficients between transformed infection type data and the percentage of leaf area infected were calculated using the PROC CORR procedure of SAS 9.4, as implemented in JMP 14.0.0. Transformed infection type (IT) data were then combined with the percentage of leaf area infected (\%LAinf), assuming a random distribution of square root values using Equation (1). Both transformed parameters contributed equally to the resulting parameter relative susceptibility.

$$
\text { Relative susceptibility }=\frac{\mathrm{IT}+\sqrt{(\% \mathrm{LAinf} / 3)}}{2}
$$

Two-way ANOVA was computed for relative susceptibility assuming a linear mixed model using the SAS PROC MIXED procedure implemented in JMP14.0.0 [29]. Isolates were considered as fixed effects, and cultivars and replicates were regarded as random. A Tukey-Kramer Honestly Significant Difference (HSD) test was performed at an alpha level of 0.05 to analyse differences between isolate means. To quantify resistance progress, linear regression analyses were performed with the year of cultivar release regarded as a continuous variable and LS-means of relative susceptibility of each pathogen, as well as isolate and cultivar as input data using the PROC MIXED procedure.

\section{RESULTS}

\section{Pathogenic Complexity of the Isolates Tested}

The virulence patterns and complexity of the rust isolates used in this study are indicated in Table 1. Virulence complexities based on pathogenicity tests on 21 differential lines range from five ("Triticale aggr.") to 16 ("Warrior + Yr27") for PS isolates with a mean of 12.3. 
"Oakley,v7/Kranich" and the Warrior isolates are relatively similar, differing primarily by virulences to Yr4 (only in the Warrior isolates), Yr27 (only moderately in "Warrior + Yr27"), and YrAmb (not in "Warrior(-)"). "Triticale aggr." differs strongly, as it is virulent to $\operatorname{Yr} 10$ and $\operatorname{Yr} 8$ while it is avirulent to Yr1, Yr3, Yr4, Yr9, Yr17, Yr25, Yr27, Yr32, YrSd, YrSu, YrSp, YrAvc.S, and YrAmb.

Table 1. Pathotypes and number of virulence or avirulence genes of Puccinia striiformis f.sp. tritici and Puccinia triticina isolates used in single isolate assays to test seedling resistance of 191 elite winter wheat cultivars. Brackets indicate ambiguous results due to the differing symptom ratings between replications or moderate susceptibility (infection type 2).

\begin{tabular}{|c|c|c|c|}
\hline $\begin{array}{l}\text { Pathogen/ } \\
\text { Pathotype }\end{array}$ & $\begin{array}{l}\text { Accession } \\
\text { number }\end{array}$ & $\begin{array}{l}\text { Virulence/ } \\
\text { Avirulence }\end{array}$ & Virulence \\
\hline \multicolumn{4}{|c|}{ P. striiformis f.sp. tritici ${ }^{a}$} \\
\hline “Triticale aggr.” & $19 / 13$ & $5 / 16$ & Yr2, Yr6, Yr7, Yr8, Yr10 \\
\hline “Oakley,v7/Kranich” & $94 / 13$ & $14 / 8$ & $\begin{array}{l}Y r 1, Y r 2, Y r 3, Y r 6, Y r 7, Y r 9, Y r 17, Y r 25,(Y r 32),(Y r S d),(Y r S u), \\
(Y r S p), Y r A v c . S,(Y r A m b)\end{array}$ \\
\hline "Warrior(-)” & $1 / 15$ & $14 / 7$ & $\begin{array}{l}Y r 1, Y r 2, Y r 3, Y r 4, Y r 6, Y r 7, Y r 9, Y r 17, Y r 25, Y r 32, Y r S d, Y r S u \\
Y r S p, Y r A v c . S\end{array}$ \\
\hline "Warrior + Yr27” & $217 / 16$ & $16 / 5$ & $\begin{array}{l}Y r 1, Y r 2, Y r 3, Y r 4, Y r 6, Y r 7, Y r 9, Y r 17, Y r 25,(Y r 27), Y r 32,(Y r S d), \\
(Y r S u), Y r S p, Y r A v c . S, Y r A m b\end{array}$ \\
\hline \multicolumn{4}{|l|}{ P. triticina $^{b}$} \\
\hline & “4083” 1 & $38 / 13$ & 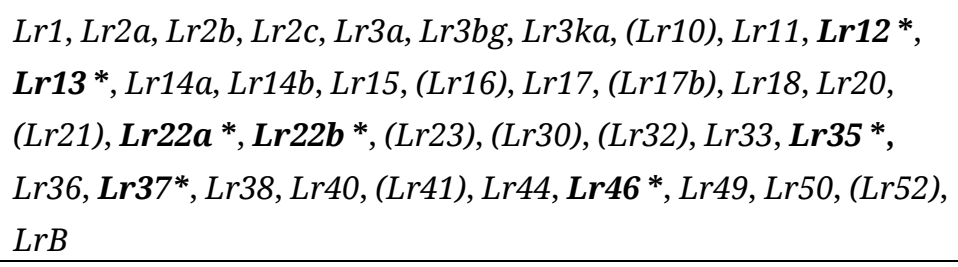 \\
\hline & “4171" 2 & $34 / 17$ & $\begin{array}{l}\operatorname{Lr} 1, \operatorname{Lr} 2 a, \operatorname{Lr} 2 b, \operatorname{Lr} 2 c, \operatorname{Lr} 11, \operatorname{Lr} 12^{*}, \operatorname{Lr} 13 *, \operatorname{Lr} 14 a, \operatorname{Lr} 14 b, \operatorname{Lr} 15, \\
(\operatorname{Lr} 16), \operatorname{Lr} 17, \operatorname{Lr} 18, \operatorname{Lr} 20, \operatorname{Lr} 21, \operatorname{Lr} 22 \boldsymbol{a}^{*}, \operatorname{Lr} 22 \boldsymbol{b}^{*}, \operatorname{Lr} 23,(\operatorname{Lr} 27), \\
\operatorname{Lr} 32, \operatorname{Lr} 33, \operatorname{Lr} 35^{*}, \operatorname{Lr} 36, \operatorname{Lr} 37^{*}, \operatorname{Lr} 38,(\operatorname{Lr} 39),(\operatorname{Lr} 40),(\operatorname{Lr} 41), \\
\operatorname{Lr} 44, \operatorname{Lr} 46^{*},(\operatorname{Lr} 48), \operatorname{Lr} 49, \operatorname{Lr} 50, \operatorname{Lr} B\end{array}$ \\
\hline & “77WxR" 3 & $41 / 10$ & 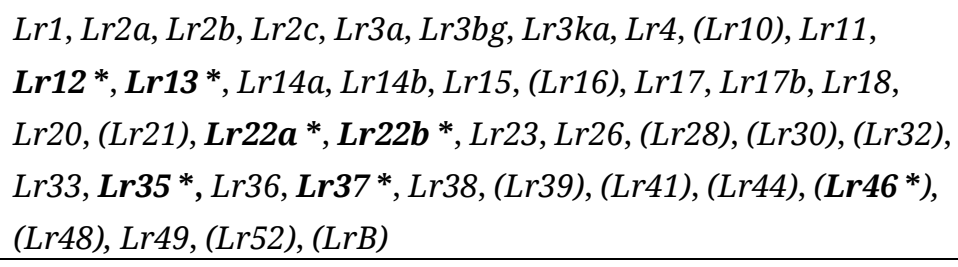 \\
\hline & “FI17” 4 & $39 / 12$ & 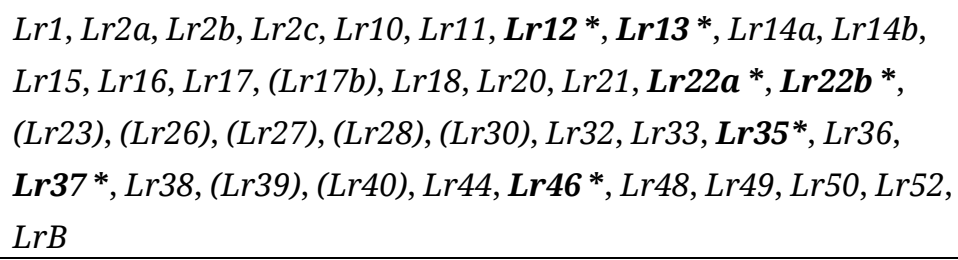 \\
\hline
\end{tabular}


Table 1. Cont.

\begin{tabular}{|c|c|c|c|}
\hline $\begin{array}{l}\text { Pathogen/ } \\
\text { Pathotype }\end{array}$ & $\begin{array}{l}\text { Accession } \\
\text { number }\end{array}$ & $\begin{array}{l}\text { Virulence/ } \\
\text { Avirulence }\end{array}$ & Virulence \\
\hline \multicolumn{4}{|c|}{ P. triticina ${ }^{b}$} \\
\hline & “HkLr13” 5 & $34 / 17$ & 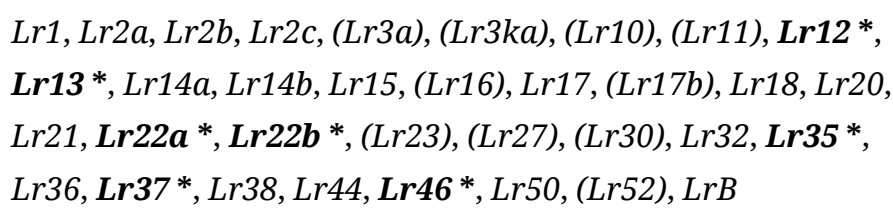 \\
\hline
\end{tabular}

*Adult Plant Resistance (APR) Lr genes against leaf rust with known race specificity;

a virulence data provided by F. Flath (JKI Kleinmachnow); tested for pathogenicity on differential genotypes carrying 21 different resistance genes: Yr1, Yr2, Yr3, Yr4, Yr5, Yr6, Yr7, Yr8, Yr9, Yr10, Yr15, Yr17, Yr24, Yr25, Yr27, Yr32, YrSd, YrSu, YrSp, YrAvc.S, YrAmb; all races isolated in Germany;

${ }^{\mathrm{b}}$ tested for pathogenicity on differential Thatcher NILs carrying 51 different resistance genes: $L r 1, \operatorname{Lr} 2 a, L r 2 b, L r 2 c, L r 3 a$, Lr3bg, Lr3ka, Lr9, Lr10, Lr11, Lr12, Lr13, Lr14a, Lr14b, Lr15, Lr16, Lr17, Lr17b, Lr18, Lr19, Lr20, Lr21, Lr22a, Lr22b, Lr23, Lr24, Lr25, Lr26, Lr27 (=Lr31), Lr28, Lr29, Lr30, Lr32, Lr33, Lr35, Lr36, Lr37, Lr38 (Tc*6/TMR-514-12-24), Lr40, Lr41, Lr44, Lr45, Lr46, Lr47, Lr48, Lr49, Lr50, Lr51, Lr52, Lr53, LrB;

1 isolated by Lind 2001, field station Aschersleben, Germany, on cultivar “Naxos” [20];

2 isolated by Lind 2001, field station Quedlinburg, Germany, on cultivar "Borenos” [20];

3 isolated by Nover and Lehmann 1967, Collection Julius-Kühn-Feld Halle, Germany [32];

${ }^{4}$ field isolate; isolated 2017 in Quedlinburg, Germany (Latitude 51.771, Longitude 11.145) on cultivar "Punch";

${ }^{5}$ field isolate; isolated 2015 in Quedlinburg, Germany (Latitude 51.771, Longitude 11.145) on “Thatcher NIL-Lr13”.

Virulence or avirulence complexities of the leaf rust isolates are substantially higher, ranging from virulence complexities of 34 (“4171”) up to 41 ("77WxR") with a mean of 37.2 , based on tests for pathogenicity on differential Thatcher NILs carrying 51 resistance genes. In total, all five $P T$ isolates differ in 17 predicted virulence genes. Precisely, " 4171 " is virulent to only eight of these $17 \mathrm{Lr}$ genes, "HkLr13" is virulent to nine, and " 4083 " as well as "77WxR" are virulent to 13 out of these 17 genes, respectively. The $P T$ isolates are relatively similar in terms of virulence against resistance genes frequently used in breeding of European bread wheat against leaf rust, such as $\operatorname{Lr} 1, \operatorname{Lr} 2 a, \operatorname{Lr} 3 a, \operatorname{Lr} 10, \operatorname{Lr} 13, \operatorname{Lr} 14 a, \operatorname{Lr} 17$, Lr20, Lr23, Lr26, Lr37, differing in virulence to Lr3a (only “4083”, “77WxR”, “HkLr13”), Lr10 (all, except “4171”), and Lr26 (“77WxR”, "FI17”), only.

\section{Response of Wheat Varieties to Rust Isolates}

Results of the analysis of the infection type response using a modified scale developed by [8] at seedling stage and percentage of infected leaf area are summarised in Table 2 and illustrated in Figure 1. “Oakley,v7/Kranich" was the most virulent PS isolate, infecting $86.4 \%$ (susceptible + resistant cultivars $=100 \%$ ) of all cultivars. In contrast, "Triticale aggr." was the least aggressive PS isolate in the panel, with $49.4 \%$ resistant cultivars. In terms of leaf rust, "HkLr13" was the most virulent $P T$ isolate in the panel (65.1\%), while the majority of the cultivars (70.7\%) were resistant to $P T$ isolate "FI17". 
The analysis of leaf damage measured in terms of percentage of leaf area infected gave comparable results. Susceptibility to all $P S$ isolates (mean $8.6 \pm 9.7 \%$ leaf area infected) was typically lower than susceptibility against $P T$ isolates (mean $10.2 \pm 13.1 \%$ ). Susceptibility was lowest against the $P S$ isolate "Triticale aggr." (2.5 $\pm 4.5 \%)$, while "Oakley,v7/Kranich" (14.8 $\pm 11.0 \%)$ caused the strongest damage. For leaf rust, susceptibility to the isolate " 4171 " $(16.6 \pm 15.7 \%)$ was highest and was rather low to "FI17" (1.6 $\pm 3.2 \%)$. All four PS isolates were significantly different from each other, as revealed by Tukey Kramer's HSD $(p \leq 0.05)$ test (Figure 1, letters in boxplot). $P T$ isolates were divided into two separate groups, namely “4083”, "4171”, together with "HkLr13" and "77WxR” with "FI17".

Transformed infection type values and the percentage of leaf area infected were combined into the relative susceptibility, as the Pearson correlation was highly significant $(p<0.001)$ with the Pearson coefficient $r=0.79$ of stripe rust and $r=0.78$ for leaf rust between both parameters, respectively.

ANOVA of relative susceptibility values reveal significant ( $p \leq 0.001)$ genetic variation among cultivars (G) as well as among isolates (I) for both rust pathogens (Table 3). Moreover, virulence of the isolates differed significantly among the cultivars, as indicated by significant $G \times I$ interaction.

Table 2. Summary of infection type response (cf. Supplementary Table S1), leaf area infected (\%), and relative susceptibility of 191 winter wheat cultivars assessed with four stripe rust and five leaf rust isolates.

\begin{tabular}{|c|c|c|c|c|c|c|c|c|c|c|c|c|c|c|c|}
\hline \multirow{2}{*}{ Pathogen/isolate } & \multicolumn{7}{|c|}{ Infection type } & \multicolumn{4}{|c|}{ Leaf area infected (\%) } & \multicolumn{4}{|c|}{ Relative susceptibility } \\
\hline & $\mathbf{0}$ & ; & $\mathrm{N}$ & 1 & 2 & 3 & 4 & Mean & SD & Min & $\operatorname{Max}$ & Mean & SD & Min & $\operatorname{Max}$ \\
\hline \multicolumn{16}{|c|}{ P. striiformis f.sp. tritici $(P S)$} \\
\hline “Oakley,v7/Kranich” & 1 & 0 & 14 & 11 & 130 & 35 & 0 & 14.77 & 10.96 & 0 & 45 & 1.84 & 0.88 & 0 & 3.37 \\
\hline “Triticale aggr.” & 1 & 4 & 80 & 12 & 72 & 22 & 0 & 2.52 & 4.49 & 0 & 24 & 0.76 & 0.79 & 0 & 2.91 \\
\hline “Warrior(-)” & 0 & 2 & 18 & 66 & 87 & 18 & 0 & 9.6 & 8.98 & 0 & 40 & 1.38 & 0.85 & 0 & 3.21 \\
\hline "Warrior + Yr27" & 0 & 2 & 46 & 26 & 9 & 22 & 0 & 7.62 & 9.08 & 0 & 40 & 1.17 & 0.96 & 0 & 3.33 \\
\hline \multicolumn{16}{|l|}{ P. triticina $(P T)$} \\
\hline “4083” & 4 & 14 & 40 & 13 & 43 & 71 & 1 & 14.1 & 13.31 & 0 & 45 & 1.76 & 1.21 & 0 & 3.83 \\
\hline “4171” & 3 & 15 & 39 & 22 & 53 & 54 & 0 & 16.64 & 15.69 & 0 & 50 & 1.76 & 1.25 & 0 & 3.54 \\
\hline “77WxR” & 15 & 54 & 0 & 28 & 65 & 28 & 0 & 3 & 4.28 & 0 & 25 & 1.02 & 0.84 & 0 & 2.72 \\
\hline “FI17” & 38 & 73 & 8 & 16 & 40 & 16 & 0 & 1.6 & 3.2 & 0 & 20 & 0.63 & 0.78 & 0 & 2.79 \\
\hline “HkLr13” & 1 & 4 & 31 & 30 & 58 & 62 & 1 & 15.81 & 13.95 & 0 & 45 & 1.88 & 1.13 & 0 & 3.63 \\
\hline
\end{tabular}


A
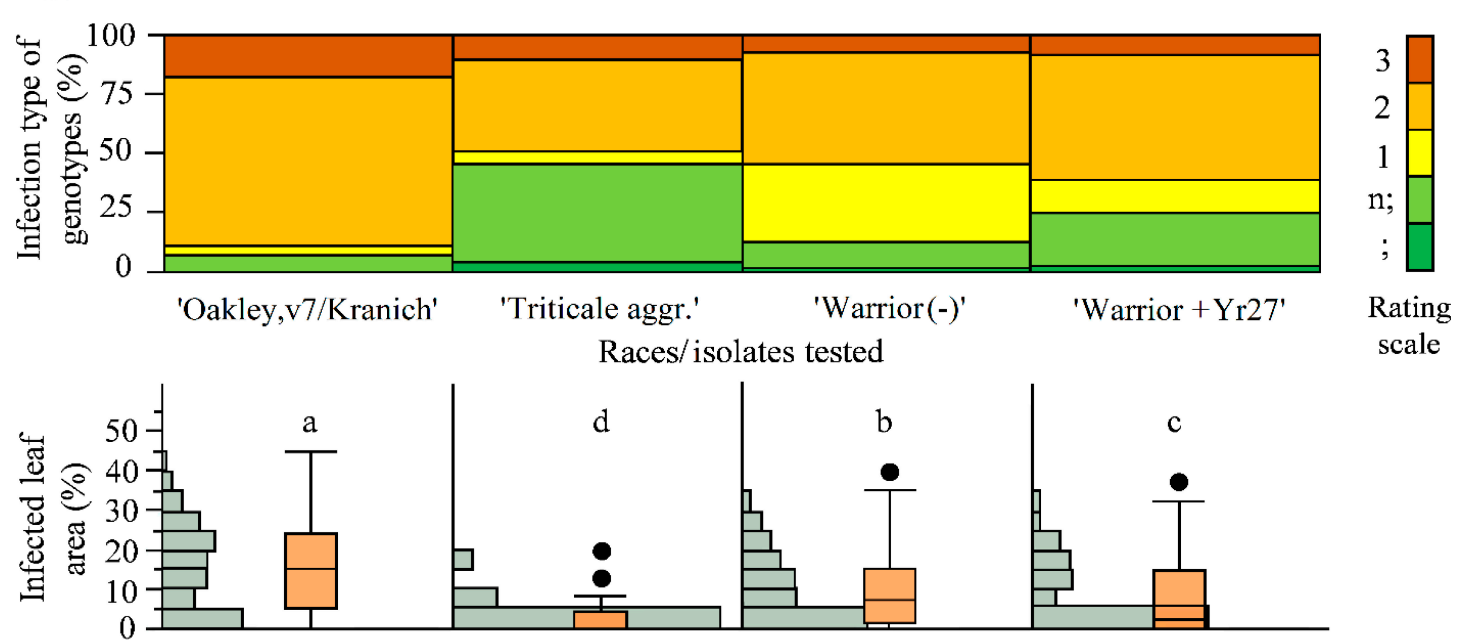

$$
\mathbf{B}
$$
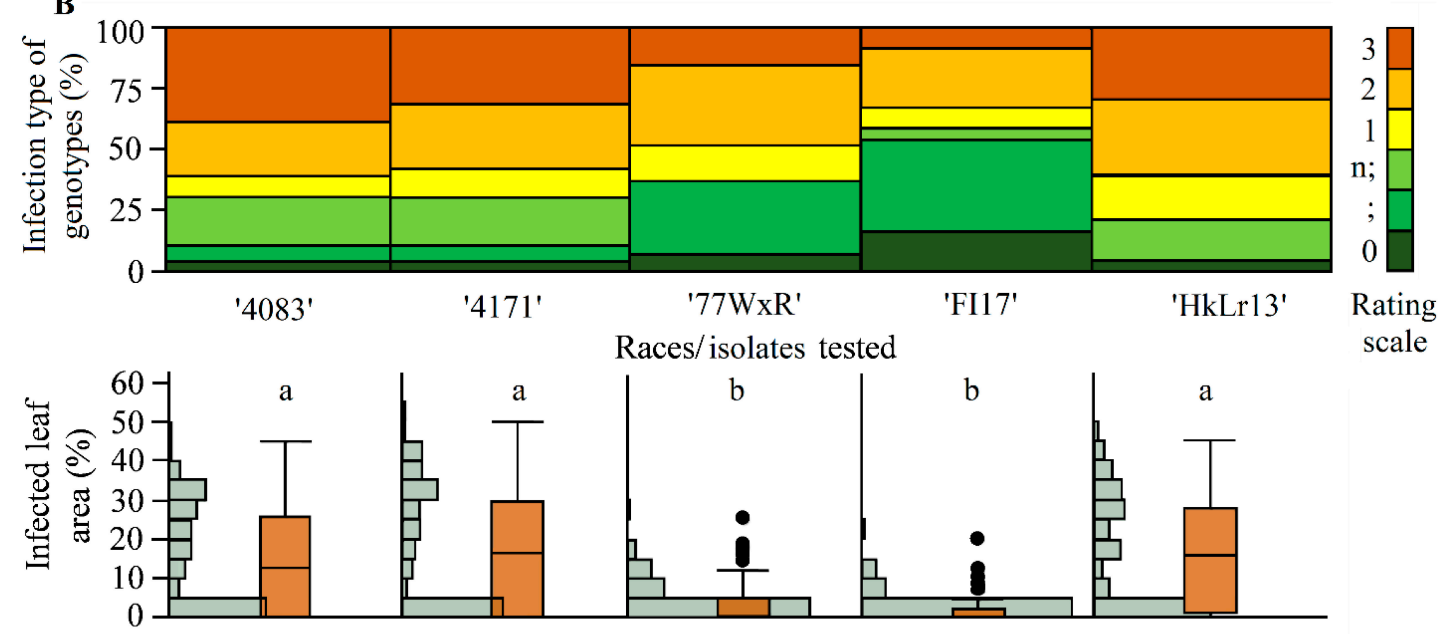

Figure 1. Analysis of susceptibility of 191 winter wheat cultivars to different isolates of $P$. striiformis and $P$. triticina. Mosaic plots of contingency tables of infection types for isolates of stripe rust (A) and leaf rust (B) and illustration of class frequencies and boxplots of infected leaf area (\%) by isolate with letters (a, b, c, d) representing groups of isolates with significant pairwise differences tested by Tukey Kramer HSD.

Table 3. ANOVA results of relative susceptibility to isolates of $P$. striiformis and $P$. triticina, each with levels of significance $\left(* * *<0.001,{ }^{* *}<0.01\right.$, and $\left.*<0.05\right)$ of 191 winter wheat cultivars tested in single isolate assays.

\begin{tabular}{lllllll}
\hline Pathogen & \multicolumn{7}{l}{ P. striiformis f.sp. tritici } & \multicolumn{4}{l}{ P. triticina } \\
\hline Source & DG & F ratio & $p>$ F & DG & F ratio & $p>$ F \\
Genotype (G) & 190 & 3.28 & $<0.0001^{* * *}$ & 190 & 10.71 & $<0.0001^{* * *}$ \\
Isolate (I) & 3 & 141.93 & $<0.0001^{* * *}$ & 4 & 150.20 & $<0.0001^{* * *}$ \\
G $\times$ I & 570 & 1.36 & $<0.0001^{* * *}$ & 760 & 4.72 & $<0.0001^{* * *}$ \\
\hline
\end{tabular}

Relative susceptibility against both rusts correlated significantly negatively with the year of cultivars' release (Table 4, Figure 2). The average annual rate of relative susceptibility, estimated based on the slope of linear regression, decreased for both groups of isolates, with $-0.015 \mathrm{a}^{-1}$ against $P S$ and with $-0.035 \mathrm{a}^{-1}$ against $P T$ isolates. Particularly strong improvements have been achieved against $P T$ isolate " 4171 " with $-0.051 \mathrm{a}^{-1}$ and against $P S$ isolate "Warrior(-)" with $-0.021 \mathrm{a}^{-1}$, respectively. Although 
the cultivar's mean susceptibilities against "Triticale aggr.”, "Oakley,v7/Kranich", and "Warrior + Yr27" were rather different, susceptibility against these $P S$ isolates decreased at about the same rate (between $-0.012 \mathrm{a}^{-1}$ and $-0.013 \mathrm{a}^{-1}$ ). The PS isolate "Oakley,v7/Kranich" caused the strongest stripe rust infestation on older cultivars, but resistance against that isolate did not improve much in modern varieties. In contrast, susceptibility to $P T$ isolate "FI17" decreased further from a relatively low base in older varieties.

Table 4. Bivariate analysis between rust isolates with the year of cultivar's release based on LS-means of relative susceptibility assuming a linear model. Additionally, phenotypic variance explained $\left(R^{2}\right)$, significance levels of $p$ values of each model tested $\left(* * *<0.001,{ }^{* *}<0.01\right.$, and $\left.{ }^{*}<0.05\right)$, and equations of linear fit to estimate breeding progress from year of release (YoR) are indicated.

\begin{tabular}{lll}
\hline Pathogen/isolate & $\boldsymbol{R}^{\mathbf{2}}$ & Equation to estimate relative susceptibility \\
\hline $\begin{array}{l}\text { P. striiformis f.sp. tritici }(P S) \\
\text { “Oakley,v7/Kranich” }\end{array}$ & $0.033^{* * *}$ & RS (Oakley,v7/Kranich) $=26.04-0.0121 \times$ YoR \\
"Triticale aggr.” & $0.045^{* * *}$ & RS (Triticale aggr.) $=26.49-0.0129 \times$ YoR \\
"Warrior(-)” & $0.109^{* * *}$ & RS (Warrior(-)) $=44.25-0.0214 \times$ YoR \\
"Warrior + Yr27” & $0.030^{* * *}$ & RS (Warrior + Yr27) $=26.56-0.0127 \times$ YoR \\
All PS isolates & $0.041^{* * *}$ & RS (all_PS) $=30.87-0.0148 \times$ YoR \\
\hline P. triticina (PT) & & \\
“4083” & $0.171^{* * *}$ & RS $(4083)=77.53-0.0379 \times$ YoR \\
“4171” & $0.268^{* * *}$ & RS $(4171)=99.4-0.0488 \times$ YoR \\
“77WxR” & $0.116^{* * *}$ & RS $(77 W x R)=44.19-0.0216 \times$ YoR \\
"FI17” & $0.173^{* * *}$ & RS (FI17) $=49.88-0.0246 \times$ YoR \\
"HkLr13” & $0.161^{* * *}$ & RS (HkLr13) $=70.41-0.0343 \times$ YoR \\
All $P T$ isolates & $0.144^{* * *}$ & RS (all_PT) $=68.57-0.0336 \times$ YoR \\
\hline
\end{tabular}
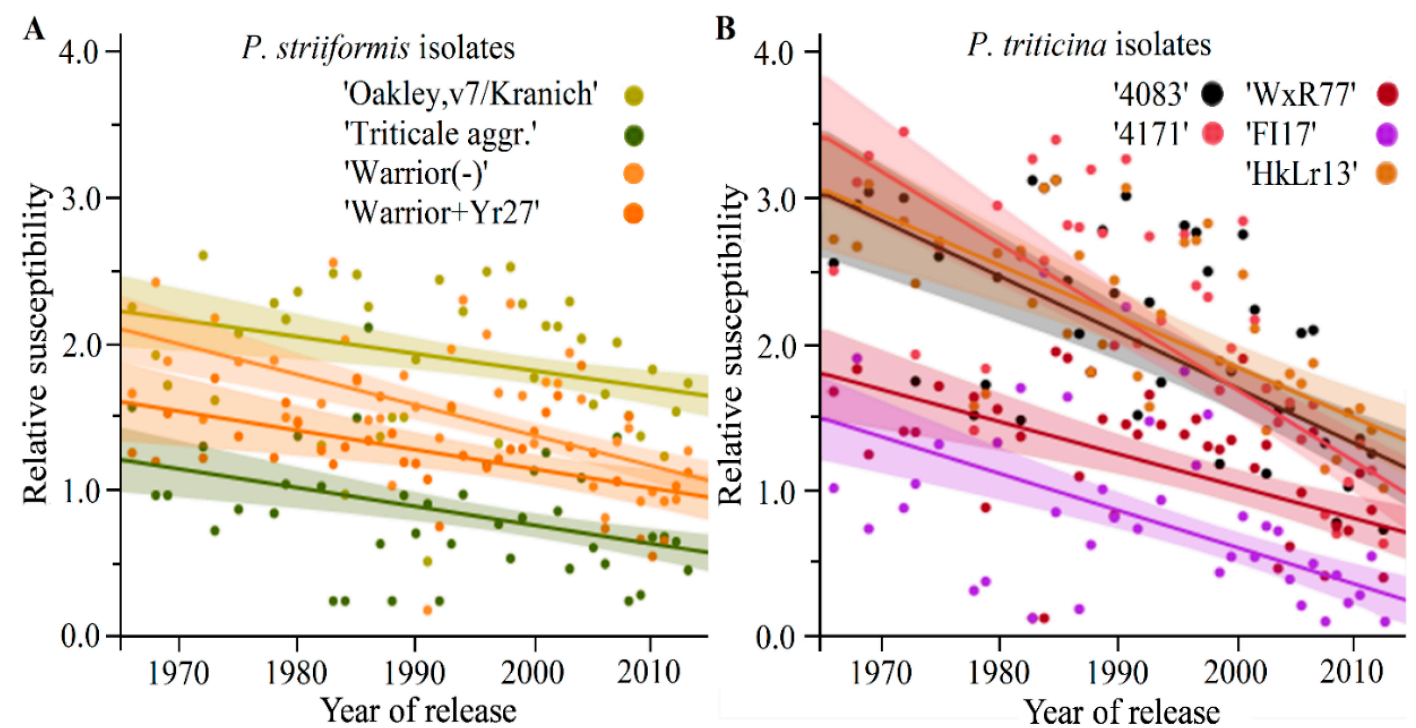

Figure 2. Breeding progress against different isolates of $P$. striiformis and P. triticina. Linear trend lines (each shaded with 95\% confidence interval) of relative susceptibility against different isolates of stripe rust (A) and leaf rust (B) based on the relative susceptibility values of 191 winter wheat cultivars in relation to the year of cultivar release. 
Breeding success is also indicated by the healthiest cultivars and their respective years of release. The best cultivars, based on mean relative susceptibility against all $P S$ isolates in the panel are "SY Ferry" (released 2012), “Zappa” (2009), "Kredo" (2009), "Potential” (2006), and “Tobak" (2011). Most susceptible were the older cultivars "Flair" (1996) and "Paroli" (2004). The cultivars Rumor (2013), "Rebell” (2013), “Kurt” (2013), "Xanthippe" (2011), and "Rebell" (2013) showed the lowest mean in relative susceptibility against all $P T$ isolates. Conversely, "Nimbus" (1975) and "Vuka" (1975) were the most susceptible.

Seedling resistance as a response to a combination of isolates was further inferred based on infection type scores (cf. Supplementary Table S1). This might be of great interest to breeders, as it maximises the number of virulences which a cultivar might face under natural conditions. 13 out of the 191 cultivars, all released after 2005, were resistant against all PS isolates. Forty-eight cultivars were resistant to all five $P T$ isolates, of which most but not all were released after 2005. A total of eight cultivars exhibited seedling resistance to all isolates of both pathogens, namely "Zappa" (2009), "Kredo" (2009), “Tabasco" (2008), "Tobak” (2011), "SY Ferry" (2012), "Xanthippe” (2011), and "Muskat" (2010). In contrast, 23 mainly older cultivars are susceptible to all rust isolates tested in this analysis.

\section{DISCUSSION}

This study focuses on the analysis of the isolate-specific resistance of wheat seedlings to stripe and leaf rust in relation to the time of cultivar release. Evidence of a steady increase in seedling resistance of European winter wheat released in Germany between 1966 and 2013 was found.

\section{Resistance against Single Rust Isolates}

Virulence complexity has increased in stripe rust in general and particularly with the occurrence of the Warrior races [18,33], which is also reflected in our selection of $P S$ isolates. However, this might be an effect of the strong selection of the latest wave of immigrated $P S$ races in relation to the increased complexity of resistance genes in winter wheat, as argued by [34].

"Triticale aggr.", the oldest stripe rust isolate in the assay, infects mainly triticale. It has been detected in Europe since 2006 [5] on triticale but could infect some wheat genotypes in our study at the seedling stage (cf. the means of "infected leaf area" between isolates in Table 1). Its relatively low pathogenicity can beexplained by its low complexity of virulence and, more importantly, that it is not virulent against R genes commonly used in recent European wheat cultivars, such as $\mathrm{Yr} 1, \mathrm{Yr} 3, \mathrm{Yr}$ 9, and $\mathrm{Yr} 32$, cf. [13]. In contrast to other stripe rust isolates "Triticale aggr." is virulent to $\operatorname{Yr} 10$ but that resistance gene has been rarely utilized in the German cultivars [35]. The Warrior races became prevalent in Europe beginning in 2011 [5]. Isolates of these races produce telia in much higher quantities even on seedlings [36]. Accordingly, susceptibility to the latter races considerably 
exceeds infestation by "Triticale aggr." in terms of both infection type and percentage of leaf area infected. Susceptibility to "Warrior(-)" is higher than to "Warrior + Yr27", which cannot be explained by Yr27. This suggests that $\mathrm{Yr} 27$ is carried rarely by the genotypes in this study. Furthermore, the virulence of "Warrior(-)" in relation to the relatively frequent R genes YrSd (Yr Strubes Dickopf) and YrSu (Suwon 92/Omar) might explain the higher infection level. Against these, only partial virulence is present in "Warrior + Yr27". Resistance against the "Oakley,v7/Kranich" isolate did not decrease much in comparison to the Warrior races. This might be attributable to the fact that "Oakley,v7/Kranich" is virulent to YrAmb and moderately virulent to $\mathrm{YrSd}$ and $\mathrm{YrSu}$ in modern cultivars, while each of the Warrior races is not or only moderately virulent to these $\mathrm{Yr}$ genes. However, minimal or no information about cultivars carrying these resistances is available. Furthermore, the differential set used in this study did not comprise all of the $80 \mathrm{Yr}$ genes which have been identified for stripe rust [37]. A possible recombination between "Oakley,v7/Kranich" and the Warrior races could result in an increased level of stripe rust infections due to a high number of virulences. However, that would require a long-distance transport of uredospores of such races, as recombination most likely will not occur in Europe [38].

A slow trend towards higher virulence complexity in European leaf rust (e.g., $L r 1, L r 2 a, L r 24, L r 25, L r 28$ and $L r 29$ ) was reported by [39], although virulence towards some $L r$ genes appears stable (e.g., $\operatorname{Lr} 2 b, \operatorname{Lr} 3 a, \operatorname{Lr} 17$ ) or fluctuating (e.g., $L r 30$ ). An increasing trend to higher virulences is not mirrored in our PT isolates, as we included old as well as recent isolates each with above- or below-average complexity. "77WxR" (isolated 1967) is the oldest, and "FI17" (isolated 2017) is the most recent leaf rust isolate in the test. However, both have a high virulence complexity (see above), but the respective mean susceptibility to them is low. "HkLr13", "4083", and "4171", with intermediate age and virulence complexity, cause higher susceptibility on the panel of wheat cultivars analysed. Although PT isolates share 25 virulences and 9 avirulences, the virulence pattern is highly complex, as illustrated in Table 1. PT isolates differ in a few virulences towards resistance genes often deployed in European elite wheat (e.g., $L r 3 a, L r 10, L r 26$ ) but also in additional virulences (e.g., $L r 27$, $L r 28, L r 33, L r 40, L r 41$ ), as well as in the aggressiveness of many virulences of which the utilisation of the respective resistance genes is not well known.

Breeding for resistances to stripe and leaf rust was lengthy in comparison to the successful control of stem rust beginning in 1915 in most parts of the world by a pyramidisation of $\mathrm{R}$ genes [7,40]. However, stem rust resistance in cultivars is based only on several genes, so that the occurrence and spread of Sr31-virulent races in the Ug99 race group caused epidemics in East Africa. Other virulent races resulted in local outbreaks in Ethiopia, Europe, and Central Asia [41]. 


\section{Breeding Progress in Seedling Resistance}

Breeding development against single isolates was estimated based on the year of cultivar release, as each isolate with its constant virulence pattern was tested on all cultivars. Susceptiblity trends differ among isolates, but improvement over time (breeding progress) can be observed against all isolates tested for both rust pathogens. Our results support and specify reports of breeding progress in adult plant resistanceto leaf rust in German winter wheat [24] and to stripe rust in Western European wheat [23] in the past five decades. Breeding progress in seedling resistance was achieved regardless of the complexity of the isolate (relatively low “Triticale aggr.”, “4171”, or high e.g., "Warrior + Yr27”, “77WxR”, “FI17”). It was neither relevant if the isolate was old ("77WxR'), relatively old (“Triticale aggr.”), or new ("FI17”, "Warrior + Yr27”). Thus, breeding progress was achieved despite the rapid changes in population dynamics in stripe rust, where isolates and races with an increasing number of virulence genes have spread in the past decades [18].

Progress has also been achieved in leaf rust, where the isolates have mostly a higher complexity and a recombinant population structure of virulence genes today [21]. Accordingly, $\mathrm{R}$ genes have not only been introduced into the European wheat cultivars of the panel but must have also been pyramidised. Otherwise, seedlings of modern cultivars would be more susceptible to at least some races within the rust population. Moreover, seedlings of modern cultivars are also more frequently resistant to a combination of isolates, while seedlings of older cultivars are among the most susceptible. Seedlings of old cultivars are also the most susceptible to low complexity and older isolates. The best explanation of these findings is that $\mathrm{R}$ genes contribute to quantitative seedling resistance of cultivars after they have been "overcome" by some isolates, such as $\mathrm{Yr}$, Yr6, Yr9, and Yr32 by "Oakley,v7/Kranich" and the Warrior isolates as well asYr27 by "Warrior + Yr27”; Lr1, Lr2a, Lr3a, Lr10, Lr14a, Lr17, Lr20, Lr23, Lr26 by “77WxR"). This conclusion supports hypothesis \#5 compiled by [42] that quantitative disease can result from $\mathrm{R}$ genes which have been broken down by virulent races. Specifically, the level of disease can be reduced in the presense of a "defeated" $R$ gene relative to the suceptibility in the absense of the respective $\mathrm{R}$ gene. That effect of "residual resistance" has been described for different pathosystems, such as wheat-powdery mildew [43], wheat-stem rust [44], and rice-Xanthomonas oryzae [45].

There is no indication that older cultivars in the panel are more resistant to older isolates and that modern cultivars are only adapted to more recent pathogen races. For example, $P S$ isolate "Triticale aggr." and $P T$ isolate "77WxR" are the oldest isolates tested of each pathogen on the panel. Although in both cases, older cultivars are less susceptible in comparison to other isolates, modern cultivars are even more resistant. That effect is similar to the response to the highly recent and aggressive $P S$ Warrior isolates, with the difference that the relative susceptibility is already higher in older cultivars. Therefore, the thesis that modern 
European elite wheat cultivars are poorly endowed against probable stressors of the future, as speculated in a recent article [46] and rejected by $[47,48]$, is not supported by our data.

\section{CONCLUSIONS}

This study represents the first attempt to assess progress in fungal seedling resistance in a large panel of European elite winter wheat cultivars responding to single isolates of stripe and leaf rust common in Europe. The results prove that a steady increase in seedling resistance was accomplished in five decades of the continuous breeding of winter wheat. An additive contribution of overcome $\mathrm{R}$ genes to seedling resistance is hypothesised.

Rust resistance breeding in European winter wheat was effective, as resistance against various isolates and races has been introduced into elite cultivars faster than resistance was lost by the emergence of pathogen races with new virulences. Thus, we conclude that the implemented breeding strategies for both higher yield potential and improved resistance was in summary highly successful.

Breeding progress in seedling resistance of European winter wheat could not be attributed to single $\mathrm{R}$ genes in this study because of the multitude of pathogen virulences and $\mathrm{R}$ genes which influence the susceptibility of a single cultivar. However, a list of cultivars with seedling resistance to a combination of the isolates tested is provided. The combined dataset of relative susceptibility will be further used in genomewide association studies (GWAS) to infer isolate specific loci of seedling resistance. Moreover, rigorous data comparison and filtering with quantitative data of susceptibility of adult plants acquired on the same panel and subsequent GWAS might allow one to infer candidate loci of further APR genes.

\section{SUPPLEMENTARY MATERIALS}

The following supplementary materials are available online at https://doi.org/10.20900/cbgg20190021, Supplementary Table S1: Infection type response of 191 European winter wheat cultivars assessed with four stripe rust and five leaf rust isolates.

\section{DATA AVAILABILITY}

The dataset of the study is available from the authors upon reasonable request.

\section{AUTHOR CONTRIBUTIONS}

HZ, AS, and FO designed the study. HZ performed the seedling experiments. AS conducted the virulence tests. HZ and AS analysed the data. HZ, AS, and FO wrote the paper with input from all authors. 


\section{CONFLICTS OF INTEREST}

The authors declare that the study was conducted in the absence of any commercial or financial relationships that could be construed as a potential conflict of interest.

\section{FUNDING}

Funding for the study was provided by the German Federal Ministry of Education and Research (BMBF, 031A354F) through Projektträger Jülich (Pt) within the project Breeding Innovations in Wheat for Efficient Cropping Systems (BRIWECS).

\section{ACKNOWLEDGMENTS}

The authors gratefully acknowledge Jana Heinze for technical assistance, Nico Pastor-Käppner and Frauke Gerken for multiplication of the rust pathogen isolates. We thank two anonymous reviewers for critically reading the manuscript and suggesting substantial improvements as well as Janine Ceschia and Stephanie Leguichard for proofreading the article.

\section{REFERENCES}

1. Zadoks JC. Yellow rust on wheat studies in epidemiology and physiologic specialization. Eur J Plant Pathol. 1961;67(3):69-256. doi: 10.1007/BF01984044

2. Roelfs AP, Singh RP, Saari EE, editors. Rust diseases of wheat: concepts and methods of disease management. Mexico (Mexico): CIMMYT; 1992.

3. Singh RP, Singh PK, Rutkoski J, Hodson DP, He X, Jørgensen LN, et al. Disease impact on wheat yield potential and prospects of genetic control. Annu Rev Phytopathol. 2016;54:303-22. doi: 10.1146/annurev-phyto-080615-095835

4. Brown JKM, Hovmøller MS. Aerial dispersal of fungi on the global and continental scales and its consequences for plant disease. Science. 2002;297:537-41. doi: 10.1126/science.1072678

5. Hovmøller MS, Walter S, Bayles R, Hubbard A, Flath K, Sommerfeldt N, et al. Replacement of the European wheat yellow rust population by new races from the centre of diversity in the near-Himalayan region. Plant Pathol. 2016;65(3):402-11. doi: 10.1111/ppa.12433

6. Flor HH. Current status of the gene-for-gene concept. Annu Rev Phytopathol. 1971;9:275-96. doi: 10.1146/annurev.py.09.090171.001423

7. Ellis JG, Lagudah ES, Spielmeyer W, Dodds PN. The past, present and future of breeding rust resistant wheat. Front Plant Sci. 2014;5:641. doi: 10.3389/fpls.2014.00641

8. McIntosh RA, Wellings CR, Park RF. Wheat rusts: an atlas of resistance genes. Clayton (Australia): Csiro Publishing; 1995.

9. Moore JW, Herrera-Foessel S, Lan C, Schnippenkoetter W, Ayliffe M, HuertaEspino J, et al. A recently evolved hexose transporter variant confers resistance to multiple pathogens in wheat. Nat Genet. 2015;47(12):1494-8. doi: 10.1038/ng.3439 
10. Herrera-Foessel SA, Lagudah ES, Huerta-Espino J, Hayden MJ, Bariana HS, Singh D, et al. New slow-rusting leaf rust and stripe rust resistance genes $\operatorname{Lr} 67$ and Yr46 in wheat are pleiotropic or closely linked. Theor Appl Genet. 2011;122(1):239-49. doi: 10.1007/s00122-010-1439-x

11. Singh RP, Huerta-Espino J, William HM. Genetics and breeding for durable resistance to leaf and stripe rusts in wheat. Turk J Agric For. 2005;29:121-7.

12. Juliana P, Singh RP, Singh PK, Crossa J, Huerta-Espino J, Lan C, et al. Genomic and pedigree-based prediction for leaf, stem, and stripe rust resistance in wheat. Theor Appl Genet. 2017;130:1415-30. doi: 10.1007/s00122-017-2897-1

13. Hovmøller MS. Sources of seedling and adult plant resistance to Puccinia striiformis f.sp. tritici in European wheats. Plant Breed. 2007;126(3):225-33. doi: 10.1111/j.1439-0523.2007.01369.x

14. Hanzalová A, Bartoš $P$, Sumíková T. Virulence of wheat leaf rust (Puccinia triticina Eriks.) in the years 2013-2015 and resistance of wheat cultivars in Slovakia. Cereal Res Commun. 2016;44(4):585-593. doi: 10.1556/0806.44.2016.030

15. Goyeau H, Lannou C. Specific resistance to leaf rust expressed at the seedling stage in cultivars grown in France from 1983 to 2007. Euphytica. 2011;178(1):45-62. doi: 10.1007/s10681-010-0261-5

16. Flath K, Bartels G. Virulenzentwicklung des Weizengelbrostes, Puccinia striiformis f.sp. tritici, in der Bundesrepublik Deutschland. In: Pflanzenschutz im Ackerbau. Festschrift anlässlich des 80. Geburtstages von Dr. Friedrich Schütte. Berlin (Germany): Parey; 2002. p. 60-6. German.

17. Kolmer JA. Tracking wheat rust on a continental scale. Curr Opin Plant Biol. 2005;8(4):441-9. doi: 10.1016/j.pbi.2005.05.001

18. Hovmøller MS, Rodriguez-Algaba J, Thach T, Justesen AF, Hansen JG. Report for Puccinia striiformis race analyses and molecular genotyping 2017. Aarhus (Denmark): Global Rust Reference Center (GRRC), Aarhus University; 2018. Available from: http://wheatrust.org/fileadmin/www.grcc.au.dk/ International Services/Pathotype YR results/Summary of Puccinia striifor mis race analysis 2017.pdf. Accessed 2019 Jun 10.

19. Ali S, Rodriguez-Algaba J, Thach T, Sørensen CK, Hansen JG, Lassen P, et al. Yellow Rust Epidemics Worldwide Were Caused by Pathogen Races from Divergent Genetic Lineages. Front Plant Sci. 2017;8:1057. doi: 10.3389/fpls.2017.01057

20. Lind V, Gultyaeva E. Virulence frequences of Puccinia triticina in Germany and the European regions of the Russian Federation. J Phytopathol. 2007;155(1):13-21. doi: 10.1111/j.1439-0434.2006.01182.x

21. Serfling A, Kramer I, Lind V, Schliepake E, Ordon F. Diagnostic value of molecular markers for $L r$ genes and characterization of leaf rust resistance of German winter wheat cultivars with regard to the stability of vertical resistance. Eur J Plant Pathol. 2011;130:559-75. doi: 10.1007/s10658011-9778-2

22. Serfling A, Luthard L, Ordon F. Charakterisierung der Virulenz einer Braunrost Feldpopulation (Puccinia triticina f.sp. tritici) und Nachweis 
effektiver Braunrostresistenzgene in Weizen (Triticum aestivum). Gesunde Pflanzen. 2011;63:135-46. doi: 10.1007/s10343-011-0260-z. German.

23. Voss-Fels K, Stahl A, Wittkop B, Lichthardt C, Nagler S, Rose T, et al. Breeding improves wheat productivity under contrasting agrochemical input levels. Nat Plants. 2019:5:706-14. doi: 10.1038/s41477-019-0445-5

24. Ahlemeyer J, Friedt W. Progress in winter wheat yield in Germany-what's the share of the genetic gain? In: Brandstetter A, Geppner M, Grausgruber H, Buchgraber K, editors. Tagungsband der 61. Jahrestagung der Vereinigung der Pflanzenzüchter und Saatgutkaufleute Österreichs, 23-25 November 2010, Raumberg-Gumpenstein, Österreich. Ertrag vs. Qualität bei Getreide, Öl und Eiweisspflanzen. Wheat stress. Irdning (Austria): Höhere Bundeslehr- und Forschungsanstalt für Landwirtschaft Raumberg-Gumpenstein; 2011. p. 19-24. German with English summary.

25. Bayles R, Flath K, Hovmøller M, de Vallavieille-Pope C. Breakdown of the Yr17 resistance to yellow rust of wheat in northern Europe. Agronomie. 2000;20(7):805-11. doi: 10.1051/agro:2000176

26. Riaz A, Periyannan S, Aitken E, Hickey L. A rapid phenotyping method for adult plant resistance to leaf rust in wheat. Plant Methods. 2016;12(1):17. doi: 10.1186/s13007-016-0117-7

27. Sharma P, Saini RG. Genetics of durable resistance to leaf rust in bread wheat cultivars capelle desprez and pari 73. J Phytol. 2011;3(10):10-5.

28. Moll E, Flath K, Tessenow I. Bewertung der Resistenz von Getreidesortimenten, Planung und Auswertung der Versuche mit Hilfe der SAS-Anwendung RESI 2. Volume 154. Quedlinburg (Germany): Julius KühnInstitut; 2010. German.

29. SAS Institute. SAS ${ }^{\circledR}$. Version 9.4. Cary (US): SAS Institute Inc.; 2015.

30. Wehner G, Kopahnke D, Richter K, Kecke S, Schikora A, Ordon F. Priming is a suitable strategy to enhance resistance towards leaf rust in barley. Phytobiomes. 2019;3(1):46-51. doi: 10.1094/PBIOMES-09-18-0041-R

31. Dracatos P, Khatkar M, Singh D, Stefanato F, Park R, Boyd L. Resistance in Australian barley (Hordeum vulgare) germplasm to the exotic pathogen Puccinia striiformis f.sp. hordei, causal agent of stripe rust. Plant Pathol. 2016;65(5):734-43. doi: 10.1111/ppa.12448

32. Nover I, Lehmann CO. Resistenzeigenschaften im Gersten-und Weizensortiment Gatersleben. Die Kulturpflanze. 1967;15(1):181-98. doi: 10.1007/BF02095713. German.

33. Fetch T, McCallum B. Increased virulence of wheat rusts and the threat to global crop production. In: Future Challenges in Crop Protection Against Fungal Pathogens. New York (US): Springer; 2014. p. 249-66.

34. Kolmer JA. Virulence dynamics, phenotypic diversity, and virulence complexity in two populations of Puccinia triticina in Canada from 1987 to 1997. Can J Bot. 1999;77(3):333-8. doi: 10.1139/b98-221

35. Flath K, Bartels G. Virulence situation in Austrian and German populations of wheat yellow rust. Arbeitstagung. 2001;2001:20-2.

36. Rodriguez-Algaba J, Walter S, Sørensen CK, Hovmøller MS, Justesen AF. Sexual structures and recombination of the wheat rust fungus Puccinia striiformis on 
Berberis vulgaris. Fungal Genet Biol. 2014;70:77-85. doi: 10.1016/j.fgb. 2014.07.005

37. Yao F, Zhang X, Ye X, Li J, Long L, Yu C, Jiang Q. Characterization of molecular diversity and genome-wide association study of stripe rust resistance at the adult plant stage in Northern Chinese wheat landraces. BMC Genet. 2019;20(1):38. doi: 10.1186/s12863-019-0736-x

38. Berlin A, Kyraschenko J, Justesen AF, Yuen J. Rust fungi forming aecia on Berberis spp. in Sweden. Plant Dis. 2013;97:1281-7. doi: 10.1094/PDIS-10-120989-RE

39. Mesterházy Á, Bartoš P, Goyeau H, Niks R, Csösz M. European virulence survey for leaf rust in wheat. Agronomie. 2000;20(7):793-804. doi: 10.1051/ agro:2000104

40. Line RF, Chen X. Successes in Breeding for and Managing Durable Resistance to Wheat Rusts. Plant Dis. 1995;79(12):1254-5.

41. Olivera PD, Rouse MN, Jin Y. Identification of New Sources of Resistance to Wheat Stem Rust in Aegilops spp. in the Tertiary Genepool of Wheat. Front Plant Sci. 2018;9(1719):1-7. doi: 10.3389/fpls.2018.01719

42. Poland JA, Balint-Kurti PJ, Wisser RJ, Pratt RC, Nelson RJ. Shades of gray: the world of quantitative disease resistance. Trends Plant Sci. 2009;14(1):21-9. doi: 10.1016/j.tplants.2008.10.006

43. Nass HA, Pedersen WL, MacKenzie DR, Nelson RR. The residual effects of some "defeated" powdery mildew resistance genes in isolines of winter wheat [Erysiphe graminis f.sp. tritici]. Phytopathology. 1981;71:1315-8.

44. Brodny U, Nelson RR, Gregory LV. Residual and interactive expressions of "defeated" wheat stem rust resistance genes. Phytopathology. 1986;76(5):546-9.

45. Li ZK, Luo LJ, Mei HW, Paterson AH, Zhao XH, Zhong DB, et al. A “defeated” rice resistance gene acts as a QTL against a virulent strain of Xanthomonas oryzae pv. oryzae. Mol Gen Genet. 1999;261(1):58-63. doi: 10.1007/s004380050941

46. Kahiluoto H, Kaseva J, Balek J, Olesen JE, Ruiz-Ramos M, Gobin A, et al. Decline in climate resilience of European wheat. Proc Natl Acad Sci U S A. 2019;116(1):123-8. doi: 10.1073/pnas.1804387115

47. Snowdon RJ, Stahl A, Wittkop B, Friedt W, Voss-Fels K, Ordon F, et al. Reduced response diversity does not negatively impact wheat climate resilience. Proc Natl Acad Sci U S A. 2019;116(22):10623-4. doi: 10.1073/pnas.1901882116

48. Piepho HP. Recent claim of declining climate resilience in European wheat is not supported by the statistics used. Proc Natl Acad Sci U S A. 2019;116(22):10625-6. doi: 10.1073/pnas.1901946116

How to cite this article:

Zetzsche H, Serfling A, Ordon F. Breeding Progress in Seedling Resistance against Various Races of Stripe and Leaf Rust in European Bread Wheat. 2019;1:e190021. https://doi.org/10.20900/cbgg20190021 